\title{
Effects of Chemical Control, Cultivar Resistance, and Structure of Cultivar Root System on Black Shank Incidence of Tobacco
}

\author{
Dimitrios F. Antonopoulos, Thomas Melton, and Asimina L. Mila, Department of Plant Pathology, North Carolina \\ State University, Raleigh 27695
}

\begin{abstract}
Antonopoulos, D. F., Melton, T., and Mila, A. L. 2010. Effects of chemical control, cultivar resistance, and structure of cultivar root system on black shank incidence of tobacco. Plant Dis. 94:613-620.

Black shank, caused by the hemibiotrophic oomycete Phytophthora parasitica var. nicotianae, is a major disease of tobacco (Nicotiana tabacum). The rise of race 1 in the late 1990s, after extensive cropping of cultivars possessing the $P h p$ gene, confirming immunity to race 0 of $P$. parasitica var. nicotianae, imposed new challenges to black shank management. The effects of tobacco cultivars and chemical controls with mefenoxam (Ridomil Gold) on black shank incidence were investigated in naturally infested fields. Twenty-five cultivars were tested and the highest resistance for races 0 and 1 of P. parasitica var. nicotianae was provided by RJR 75 and SP 227 based on field and laboratory studies. When race 1 was prevalent, mefenoxam was effective to control black shank. An initial application at an early stage of tobacco growth, such as a few days before or after transplant, was essential to successfully control the disease. In greenhouse experiments, cultivars carrying the $P h p$ gene produced fewer and shorter adventitious roots than cultivars possessing only partial resistance to all races of P. parasitica var. nicotianae. Strategies such as use of mefenoxam, especially at an early stage, when adventitious roots are emerging, and planting a cultivar with high partial resistance or possessing the $P h$ gene when race 1 or race 0 , respectively, predominates are critical factors in reducing loss due to $P$. parasitica var. nicotianae.
\end{abstract}

Black shank, caused by the hemibiotrophic oomycete Phytophthora parasitica (Dastur) var. nicotianae (van Breda de Haan) Tucker (syn. P. nicotianae Breda de Haan var. nicotianae Waterhouse, P. nicotianae van Breda de Haan), is a destructive pathogen of tobacco (Nicotiana tabacum Solanaceae) worldwide. P. parasitica var. nicotianae can infect tobacco roots, stems, and leaves at any stage of plant growth, resulting in wilting, stem lesions, and plant death (35). Annual yield losses of the fluecured tobacco crop due to $P$. parasitica var. nicotianae in North Carolina range from 1 to $3 \%$, resulting in millions of U.S. dollars in lost revenue (33).

Currently, the main known sources of resistance to $P$. parasitica var. nicotianae are the following: (i) the cigar-wrapper $N$. tabacum cv. Florida $301(42,45)$, (ii) the cigar-type tobacco cv. Beinhart 1000-1 (5,37), (iii) $N$. longiflora Cav. (43), and (iv) N. plumbaginifolia Viv. (4). Four different $P$. parasitica var. nicotianae physiological races $(0,1,2$, and 3$)$ have been reported to occur on tobacco based on their

Corresponding author: Asimina Mila

E-mail: almila@ncsu.edu

Accepted for publication 2 February 2010.

doi:10.1094/PDIS-94-5-0613

(C) 2010 The American Phytopathological Society ability to infect cultivars or breeding lines with different resistance backgrounds $(1,22,28,31)$. Races 0 and 1 are present in North Carolina (2); race 2 has been reported in South Africa $(29,44)$; and race 3 is present in Connecticut, North Carolina, and Virginia $(18,31)$. Races are similar in morphology but differ in cultural, physiological, biochemical, and pathological characteristics $(1,8,31,42)$.

Single-gene resistance to $P$. parasitica var. nicotianae from $N$. longiflora $(P h l)$ and $N$. plumbaginifolia ( $P h p)$ has been incorporated into burley and flue-cured tobacco cultivars, respectively $(1,4)$. Single-gene resistance provides complete resistance to race 0 but no resistance to race 1 of $P$. parasitica var. nicotianae $(1,4,43)$. Studies have shown that $P h p$ and $P h l$ genes respond identically to race 0 and race 1 of $P$. parasitica var. nicotianae (43) and are homologous in function in the breeding lines NC 1071 and L8, respectively $(7,19)$. Nevertheless, they may be members of a complex resistance locus (22). Both lines have been used as indicator cultivars to detect race 1 (NC 1071) or race 3 (L8) in trials conducted in naturally infested fields in North Carolina $(12,22,43)$.

Race 0 was the predominate race of $P$. parasitica var. nicotianae in the flue-cured tobacco-growing areas in North Carolina (33). Race 1 occurs only under intense selection pressure resulting from continu- ous cultivation of cultivars possessing the $P h p$ or $P h l$ genes that confirm resistance against race $0(2,30)$. The flue-cured $\mathrm{cv}$. NC 71, released in 1995, was a hybrid with the Php gene and was extensively deployed in North Carolina, due to high yields with excellent quality. In the late 1990 s, as the popularity of cultivars possessing the Php gene increased, so did race 1 (39). The majority of commercial tobacco cultivars currently grown have the Php gene and, thus, the deployment of this type of resistance continues to be extensive (33).

An important consideration in analyses of epidemics by soilborne pathogens is the role of root growth of the host. Root growth contributes to epidemic development by providing opportunity for contact between a host and pathogen propagules (23). In a previous study (26), flue-cured tobacco cultivars with a low level of resistance had larger root systems than moderate to highly resistant cultivars and, therefore, were more likely to come in contact with pathogen propagules. Standard commercial tobacco transplanting practice involves burying 4 to $10 \mathrm{~cm}$ of the stem into the soil. Copious fine, adventitious roots are produced from the buried stem, in contrast to the fewer, but thicker, "true" roots arising from the buried base of the transplant (13). These roots are responsible for the majority of water and nutrient uptake in actively growing plants. It is not known whether the presence of $p h p$ gene affects their density, although it could be important to black shank epidemic development.

A combination of practices is required to successfully manage black shank. Losses can reach $100 \%$ when no disease management practices are used (33). An integrated approach is recommended for managing black shank that includes cultural practices such as crop rotation and destruction of plant debris at the end of the growing season, planting resistant cultivars, and fungicide applications $(33,35)$. Phenylamides, such as metalaxyl and metalaxyl-m (mefenoxam), are highly systemic fungicides having the capacity to xylem-translocate throughout plants, with selective toxicity against Oomycetes (6). Metalaxyl is used worldwide for the control of many Phytophthora diseases, including black shank (27). This fungicide protects tobacco seedlings by inhibiting growth of $P$. parasitica var. nicotianae mycelium and formation of 
sporangia $(34,38)$. Mefenoxam consists of a 94:3 ratio of $R$ - to $S$ - metalaxyl enantiomers and has been commercially used since 1996 as Ridomil Gold.

The objectives of this study were to investigate the following: (i) the effect of flue-cured cultivars with different sources of resistance on black shank incidence and (ii) the efficacy of mefenoxam applied at various stages of tobacco growth on black shank incidence, when race 0 or race 1 of $P$. parasitica var. nicotianae predominates. Experiments were conducted in fields naturally infested with both races of $P$. parasitica var. nicotianae. Due to the high prevalence of race 1 of $P$. parasitica var. nicotianae in most flue-cured tobacco fields, the black shank resistance to race 0 of $P$. parasitica var. nicotianae on cultivars recently introduced to the United States was further investigated under laboratory conditions. In 2008, greenhouse experiments were conducted to complement field studies by investigating differences in root system structure among flue-cured tobacco cultivars with different sources of resistance to black shank.

\section{MATERIALS AND METHODS}

Resistance of tobacco cultivars to $P$. parasitica var. nicotianae in on-farm studies. Ten studies were conducted between the 2002 and 2008 tobacco-growing seasons in fields in six counties of North Carolina (Hoke, Iredell, Martin, Rockingham, Surry, and Yadkin) to give a total of 10 different North Carolina environments. Three studies were conducted in fields with predominate race 0 of $P$. parasitica var. nicotianae (Hoke and Martin Counties) and seven in fields where race 1 of $P$. parasitica var. nicotianae was the predominant race (Iredell, Rockingham, Surry, and Yadkin Counties). Twenty-five cultivars with partial or complete resistance to $P$. parasitica var. nicotianae races 0 and 1 were evaluated (Table 1). CC 13, K 149, K 326, K 346, K 394, NC 55 NC 606 , and SP 210 have various levels of partial resistance inherited from Florida 301 for all races of $P$. parasitica var. nico- tianae (group I). CC 37, NC 102, NC 196, NC 291, NC 297, NC 471, NC 71, NC72, SP 168, SP 179, SP 220, SP 225, SP 227 , and SP 236 have the Php gene that confirms complete resistance to race 0 and various levels of partial resistance from Florida 301 (group II). Cultivars of groups I and II are extensively used in the fluecured tobacco-producing areas of the United States (33). Detailed pedigree information of these tobacco cultivars is available from Johnson et al. (24), and Fisher et al. (17). CC 35 and RJR 75 have resistance that originated from Zimbabwe, introduced in the United States in 2008, and also possess the Php gene (group III). RJR 15 has resistance originated from Zimbabwe but not the Php gene (group IV).

The prevalence of $P$. parasitica var. nicotianae races in each on-farm study was monitored by the inclusion of the breeding lines NC 1071 and L8 along with the tested cultivars. Tobacco cultivars were arranged in a randomized complete block design consisting of a one-row plot (1.17 $\mathrm{m}$ wide and $15.24 \mathrm{~m}$ long) with four replications (except for the studies in Hoke County in 2002, 2003, and 2004 that had three replications). Tobacco cultivars were transplanted between 3 and 21 May of each year. Recommended cultural practices were followed throughout the season. Plant stand was measured 3 weeks after transplanting. Black shank incidence was evaluated at each study by counting the number of tobacco plants with characteristic aboveground symptoms. That is, plants with leaves that were permanently wilted, stunted, and had a black lesion at the base of the stem. Evaluation was conducted once every 2 weeks, beginning 4 to 6 weeks after transplanting depending on tobacco growth rate and environmental conditions. The last evaluation was done 14 to 18 weeks after transplanting for a total of five evaluations. The disease index (DI) was calculated for all cultivars in each field study from disease incidence evaluations, with earlier evaluations were more heavily weighted than the later ones ac- cording to Csinos et al. (11). Specifically, for five evaluations the formula is DI = $\left[\Sigma_{\mathrm{i}=\mathrm{i}-5} X_{i}(100-[i-1])(100 / n)\right] / N$, where $i$ is an ordinal evaluation number, $n$ is the number of disease evaluations, $X$ is the number of diseased plants since the last count, and $N$ is the total number of plants. Therefore, the DI is a measurement of disease progress over time and disease severity. No yield data were collected from these field studies.

Laboratory experiments to investigate cultivar resistance to $P$. parasitica var. nicotianae races. Cvs. RJR 15 and RJR 75 possess resistance newly introduced to the United States. The high prevalence of race 1 of $P$. parasitica var. nicotianae in most flue-cured tobacco fields (32) does not allow the evaluation of these cultivars under field conditions where race 0 is the prevalent one. Therefore, RJR 15 and RJR 75 were further evaluated for their resistance to $P$. parasitica var. nicotianae races in a laboratory experiment. They were compared with three cultivars: K 346 (group I), NC 71 (group II), and L8 (a burley tobacco breeding line possessing the $P h l$ gene that is used to identify race 3 of $P$. parasitica var. nicotianae) (18). The experiment was conducted using the technique described by Gutierrez et al. (20). Tobacco cultivars were grown in tissue culture (TC) plates (Corning Incorporated; Corning, NY). Each cell of the plate was filled with $3.5 \mathrm{~cm}^{3}$ of perlite $(<2 \mathrm{~mm}$ in size) and $1.5 \mathrm{ml}$ of deionized water. Five to eight seeds were placed in each cell (one cultivar per cell). Seeded plates were then incubated under $12 \mathrm{~h}$ of darkness and $12 \mathrm{~h}$ of light at room temperature $\left(20\right.$ to $\left.25^{\circ} \mathrm{C}\right)$. Then, $0.5 \mathrm{ml}$ of a 200-ppm $\mathrm{N}$ fertilizer solution (Bulldog water-soluble fertilizer 20-10-20; Chilean Nitrate Corporation, Northfolk, VA) per cell was added 10 days after seeding and weekly thereafter. Seedlings (25 days old) were inoculated by placing one piece of a colonized Catharanthus roseus (syn. Vinca rosea) leaf disc (5 $\mathrm{mm}$ in diameter) per cell. Following inoculation, sets of $16 \mathrm{TC}$ plates were placed into a 52-by-27-by-16-cm plastic container

Table 1. Tobacco cultivars evaluated for their resistance to black shank, caused by Phytophthora parasitica var. nicotianae, in on-farm studies in North Carolina between the 2002 and 2008 tobacco-growing seasons

County (year)

Cultivar $^{2}$

Iredell (2007), Rockingham (2007), Surry (2007), Yadkin (2007),

Iredell (2008), Martin (2008), Yadkin (2008)

Iredell (2008), Martin (2008), Yadkin (2008)

Hoke (2002), Hoke (2003), Hoke (2004), Rockingham (2007),

Surry (2007), Yadkin (2007)

Hoke (2002), Hoke (2003), Hoke (2004)

Hoke (2004), Iredell (2008), Martin (2008), Yadkin (2008)

Hoke (2004), Iredell (2007), Rockingham (2007), Surry (2007),

Yadkin (2007), Iredell (2008), Martin (2008), Yadkin (2008)

Hoke (2003), Hoke (2004), Iredell (2007), Rockingham (2007),

Surry (2007), Yadkin (2007)

Hoke (2003), Hoke (2004), Iredell (2007), Rockingham (2007),

Surry (2007), Yadkin (2007), Iredell (2008), Martin (2008), Yadkin (2008)

\footnotetext{
${ }^{\mathrm{z}}$ For pedigree information and genetic background related to resistance to P. parasitica var. nicotianae, see Johnson et al. (24); North Carolina Crop Improvement Association (NCCIA), 2009 (online); and Fisher et al. (17).
}

CC 13, CC 37, RJR 15, SP 236

CC 35, RJR 75

K 149, K 326, K 346, NC 297, NC 55, NC 606, NC 71, NC 72, SP 168 , SP 210, SP 220

K 394, SP 179

NC 102

NC 196, NC 471

NC 291, SP 225

SP 227 
(Sterlite Co., Townsend, MA) and covered with a 55-by-46-cm polyvinyl-chloride laboratory wrap (Fisher Scientific Company, Pittsburgh, PA) to create moist chamber conditions. The containers were then incubated in a growth chamber at $27.5^{\circ} \mathrm{C}$ with $13 \mathrm{~h}$ of light and $23^{\circ} \mathrm{C}$ with 11 $\mathrm{h}$ of darkness. Each cultivar was seeded in two cells of each TC plate. One isolate was inoculated per plate and two plates were used per isolate. The experiment was repeated once.

Races of $P$. parasitica var. nicotianae used were (i) race 0 , isolated from Rockingham county in summer of 2007; (ii) race 1, isolated from Yadkin county in summer of 2008; and (iii) race 3, isolated from Martin county in summer of 2008 . Two isolates per race were used that were isolated from infected pith tissue of tobacco plants of cv. K 326 for (i), CC 13 and SP 227 for (ii), and CC 13 for (iii) after culture on selective PARPH medium (40). P. parasitica var. nicotianae isolates were race characterized with a differential host test described by Gutierrez et al. (20) before their use in the laboratory experiments.

Effect of chemical controls on black shank incidence in on-farm studies. The effectiveness of mefenoxam to control races 0 and 1 of $P$. parasitica var. nicotianae in combination with cultivars of different resistance was investigated in naturally infested tobacco fields. Two types of studies were conducted: (i) in fields with race 0 of $P$. parasitica var. nicotianae, to investigate whether the standard recommendation that called for use of resistant cultivars and three applications of mefenoxam (i.e., before transplanting, at first cultivation, and again at last cultivation of tobacco) was still appropriate or should be modified to reflect the introduction of resistant cultivars to $P$. parasitica var. nicotianae race 0 ; and (ii) in fields with race 1 of $P$. parasitica var. nicotianae, to investigate the efficacy of mefenoxam when race 1 is prevalent and cultivars with or without the $p h p$ gene are planted.

For (i), on-farm studies were conducted in 2001 (in Bladen County) and in 2002 (in Hoke County) to give a total of two different environments. Cvs. K 346 (group I) and NC 71 (group II) were transplanted 4 May (Bladen County) and 7 May (Hoke County). Soil-directed mefenoxam treatments were applied (i) before transplanting; (ii) before transplanting, at first cultivation, and at last cultivation (layby); and (iii) only at the first cultivation of tobacco growth stages. Before transplanting, application of mefenoxam was broadcast applied at the rate of 1.17 liter ha $\mathrm{h}^{-1}$ and then incorporated in the soil with a field cultivator 1 to 7 days before plants were transplanted. Mefenoxam treatments at first cultivation and layby were made 10 to 20 and 47 to 59 days after transplanting, respectively, depending on tobacco growth rate and weather conditions. Mefenoxam was applied at 1.17 liter ha ${ }^{-1}$ in a $61-\mathrm{cm}$ band on both sides of the row immediately prior to cultivation in order to be incorporated into the soil.

For study (ii), on-farm studies were conducted in 2007 in Forsyth and Surry counties (for a total of two different environments). Flue-cured tobacco cvs. K 326 (group I) and NC 71 (group II) were transplanted on 15 May (Forsyth County) and 17 May (Surry County). The mefenoxam treatments in these studies were (i) before transplanting, at first cultivation, and at layby; (ii) at first cultivation and layby; or (iii) only at layby. Mefenoxam treatments before transplanting were applied 3 to 7 days before transplant; those at first cultivation and layby were made 23 to 25 and 51 to 65 days after transplanting, respectively. All mefenoxam treatments were applied at the rate and method described for the field studies conducted in 2001 and 2002.

Studies were arranged in a randomized complete block design consisting of plots of one 1.17-m-wide row, $15.24 \mathrm{~m}$ in length, with four replications. Treated rows were separated by a nontreated row (i.e., skip row) of tobacco plants. A nontreated control was included in all studies. Plant stand was measured 3 weeks after transplanting. Black shank incidence was evaluated in each study by counting the number of tobacco plants with leaves that were permanently wilted, stunted, and had a black lesion at the base of the stem. Evaluation was conducted once every 2 weeks, beginning 5 to 6 weeks after transplanting depending on tobacco growth rate and environmental conditions for a total of four evaluations. The DI was calculated for all cultivars in each field study from disease incidence evaluations, with earlier evaluations more heavily weighted than the later ones according to Csinos et al. (11). Specifically for four evaluations the formula is: $\mathrm{DI}=\left[\Sigma_{\mathrm{i}}=\mathrm{i}-4 X_{i}(100-[i-\right.$ 1])(100/n)]/N, where $i$ is an ordinal evaluation number, $n$ is the number of disease evaluations, $X$ is the number of diseased plants since the last count, and $N$ is the total number of plants. No yield data were collected from these field studies. Plants of flue-cured tobacco cultivars were produced in float beds in growers' greenhouses in each county. The soil types were Norfolk loamy sand (Bladen, Hoke, and Surry Counties) and Pacolet clay loam (Forsyth County). The predominant race in each tobacco field was assumed based on the mortality observed on NC 71. In each location, the soil $\mathrm{pH}$ was approximately 6.0. All normal cultural practices for the area were followed throughout the season. No yield data were collected.

Root system structure of flue-cured tobacco cultivars with different types of resistance to $P$. parasitica var. nicotianae. The ability of two representative cultivars of group I (K 326 and K 346) and group II (NC 196 and SP 227) to produce adventitious roots from the stalk portion of the stem buried in the soil was investigated in greenhouse experiments. Cultivars were seeded into polystyrene trays (2.4-by-2.4$\mathrm{cm}$ pot size), filled with Carolina's Choice pot-mix (Carolina's Soil Company, Kingston, NC) and allowed to grow in a greenhouse $\left(25 \pm 3^{\circ} \mathrm{C}, 12\right.$-hr photoperiod). Miracle-Gro water-soluble 24-8-16 (Scott's Miracle Gro Products, Marysville, $\mathrm{OH}$ ) at 100 ppm was applied 7 and 21 days after seeding in the water. Plants were clipped every 3 days beginning 28 days after seeding according to standard practices implemented in greenhouse tobacco production (21). In all, 36 60-day-old tobacco seedlings ( 9 per cultivar) were transplanted in 11-by-11-by-30-cm (length by width by height) Plexiglas boxes (one plant per box) close to the removable transparent side, so that $5 \mathrm{~cm}$ of the stalk base could be covered with the soil mixture, simulating the depth of tobacco field-grown transplants. The soil mixture consisted of steampasteurized field soil, coarse builder's sand, Metromix 220 (The Scotts Company, Marysville, $\mathrm{OH}$ ), and perlite, 1:1:1:0.5 ( vol/vol). All tobacco transplants were watered with $250 \mathrm{ml}$ of water every 4 days. Eighteen days after transplant, tobacco seedlings were carefully uprooted and the soil particles were removed from the root system. Afterward, the number and length of adventitious roots of all tobacco plants were recorded. The experiment was conducted three times.

Statistical analysis. Exploratory analyses indicated heterogeneous variances that were corrected with logarithmic transformations. To evaluate cultivar resistance in the field studies, mean comparisons of the black shank indices were conducted using the general linear model procedure (PROC GLM) of the Statistical Analysis System (version 9.1; SAS Institute Inc., Cary, NC). $F$ tests were used to determine significant effects on black shank indices. Effects (category or class variables) examined were cultivar planted, field environment, and their interactions. Due to the unbalanced nature of the data, inference was based on type III sum of squares.

Data from the laboratory experiments were examined using an analysis of variance (PROC ANOVA; SAS, version 9.1) and means were separated according to Fisher's least significant difference test (FLSD) at $P \leq 0.05$. Bartlett's test for homogeneity of variances was conducted to evaluate the possibility of combining data from the two experiments before further analysis was conducted.

DI data from the chemical control field studies were logarithmically transformed and then subjected to analyses of variance using the PROC GLM of the Statistical Analysis System, (SAS, version 9.1). F tests were used to determine significant 
effects on black shank index. Effects (category or class variables) examined were cultivar planted, mefenoxam application, field environment, and their interactions. Due to the unbalanced nature of the data, inference was based on type III sum of squares.

For the greenhouse root system structure experiments, Bartlett's test for homogeneity of variances was conducted to evaluate whether data from the three trials could be combined for number and average length of adventitious roots. Data were subsequently analyzed using PROC ANOVA (SAS, version 9.1). Means were separated according to FLSD test at $P \leq 0.05$.

\section{RESULTS}

Resistance of tobacco cultivars to $P$. parasitica var. nicotianae in on-farm studies. Tobacco cultivar, field environment, and their interaction had a significant effect on black shank index for both race 0 and race 1 of $P$. parasitica var. nicotianae (Table 2). Disease symptoms were first observed 48 to 56 and 33 to 64 days after transplanting in fields where race 0 or 1 , respectively, predominated. In fields where race 0 was predominant, black shank progressed faster than in fields with race 1 (Table 3 ). The lowest black shank indices recorded in the fields where race 0 was predominant were for the cultivars carrying the Php gene (Table 3). Under race 1 prevalence, several of the cultivars of group II had DIs equivalent to the ones calculated for cultivars of group I (Table 3). A few cultivars of group II, such as SP 220, SP 225, SP 227, and SP 236, had a low DI equivalent to K 346 (group I), an indication that these cultivars, beyond possessing the Php gene, have high partial resistance to all races of $P$. parasitica var. nicotianae. The newly introduced cultivars CC 35, RJR 75 (group III), and RJR 15 (group IV) had low DIs in fields with predominate race 1 (Table 3 ).

Laboratory experiments to investigate cultivar resistance to $P$. parasitica var. nicotianae races. All cultivars developed black shank symptoms 7 days after inoculation with race 1, with RJR 15 and K 346 having the lowest black shank incidence. Only K 346 with race 0 and K 346 and
RJR 15 with race 3 had symptomatic plants (Table 4). At 14 days after inoculation, plants of L8, NC 71, and RJR 75 inoculated with races 0 and 3 of $P$. parasitica var. nicotianae had no black shank symptoms whereas all cultivars had visual black shank symptoms with race 1 . L8 and NC 71 had statistically higher incidence than RJR 15 and K 346 (Table 4). At 21 days after inoculation, the highest percentage of diseased tobacco seedlings with race 1 was observed in $\mathrm{L} 8, \mathrm{NC} 71$, and
RJR 75, which was significantly higher than for K 346 and RJR 15 (Table 4). These results are partially consistent with DIs obtained in field studies where K 346 and RJR 15 were among the cultivars that had low DIs under race 1 prevalence (Table 3); however, in field studies, RJR 75 also had a low DI, an indication that environment may have a profound effect on expression of this type of resistance. Interestingly, under laboratory conditions, the resistance incorporated in RJR 15, which

Table 3. Black shank disease index (DI) of flue-cured tobacco cultivars when race 0 or race 1 of $P$ hytophthora parasitica var. nicotianae was the predominate race in on-farm studies during the 2002 to 2008 growing seasons in North Carolina ${ }^{\mathrm{y}}$

\begin{tabular}{|c|c|c|c|c|}
\hline \multirow[b]{2}{*}{ Cultivar $^{\mathrm{z}}$} & \multicolumn{2}{|c|}{ Race 0} & \multicolumn{2}{|c|}{ Race 1} \\
\hline & Sites tested & DI & Sites tested & DI \\
\hline \multicolumn{5}{|l|}{ Group I } \\
\hline CC 13 & $\ldots$ & ND & 6 & 10 \\
\hline K 149 & 2 & 21 & 5 & 17 \\
\hline K 326 & 2 & 38 & 5 & 22 \\
\hline K 346 & 2 & 20 & 5 & 6.7 \\
\hline K 394 & 2 & 52.4 & $\ldots$ & ND \\
\hline NC 55 & 2 & 34.3 & 5 & 33 \\
\hline NC 606 & 2 & 15.2 & 5 & 14 \\
\hline SP 210 & 2 & 16.5 & 5 & 14 \\
\hline \multicolumn{5}{|l|}{ Group II } \\
\hline CC 37 & $\ldots$ & ND & 6 & 21 \\
\hline NC 102 & 2 & 8.5 & 2 & 15 \\
\hline NC 196 & $\ldots$ & ND & 6 & 14 \\
\hline NC291 & 2 & 0 & 5 & 16 \\
\hline NC 297 & 2 & 0 & 5 & 15 \\
\hline NC 471 & $\ldots$ & ND & 7 & 8.5 \\
\hline NC 71 & 3 & 0.4 & 5 & 16 \\
\hline NC 72 & 3 & 2 & 5 & 14 \\
\hline SP 168 & 3 & 6 & 5 & 11 \\
\hline SP 179 & 2 & 0 & $\ldots$ & ND \\
\hline SP 220 & 3 & 0.6 & 5 & 8 \\
\hline SP 225 & 2 & 0 & 5 & 8 \\
\hline SP 227 & 2 & 0 & 6 & 4 \\
\hline SP 236 & $\ldots$ & ND & 6 & 6 \\
\hline \multicolumn{5}{|l|}{ Group III } \\
\hline CC 35 & $\ldots$ & ND & 2 & 2 \\
\hline RJR 75 & $\ldots$ & ND & 2 & 4 \\
\hline \multicolumn{5}{|l|}{ Group IV } \\
\hline RJR 15 & $\ldots$ & ND & 6 & 9.5 \\
\hline
\end{tabular}

${ }^{y}$ DI was calculated in each field study from disease incidence evaluations, with earlier evaluations more heavily weighted than the later ones. Each value represents the mean of sites tested. A disease index of 0 indicates no detectable levels of black shank while that of 100 indicates that all plants had died within the period of evaluations; ND = no data.

${ }^{\mathrm{z}}$ Group I has various levels of partial resistance inherited from Florida 301; group II has the Php gene and various levels of partial resistance from Florida 301; group III has resistance recently introduced to the United States from Zimbabwe and the Php gene; and group IV has the same resistance as group III but without the Php gene. Predominate race of $P$. parasitica var. nicotianae in each field was determined based on black shank incidence on cv. NC 1071 that has the Php gene and very low partial resistance from Florida 301.

Table 2. Effect of flue-cured tobacco cultivar and field environment on black shank disease index when race 0 or race 1 of Phytophthora parasitica var. nicotianae was the predominate race in on-farm studies during the 2002 to 2008 growing seasons ${ }^{\mathrm{w}}$

\begin{tabular}{|c|c|c|c|c|c|c|}
\hline \multirow[b]{2}{*}{ Source of variation ${ }^{x}$} & \multicolumn{3}{|c|}{ Race 0} & \multicolumn{3}{|c|}{ Race 1} \\
\hline & df & $\mathbf{M S}^{\mathbf{y}}$ & $F$ value $^{\mathrm{z}}$ & df & $\mathbf{M S}^{\mathbf{y}}$ & $F$ value $^{\mathrm{z}}$ \\
\hline Cultivar & 28 & $1,026.5$ & $10.33 *$ & 28 & 2,175 & $11.70 *$ \\
\hline Field environment & 2 & 7,895 & $82.30 *$ & 6 & 1,882 & $10.13 *$ \\
\hline Cultivar $\times$ field environment & 19 & 787.5 & $8.20 *$ & 99 & 247.4 & $1.33 * *$ \\
\hline
\end{tabular}

${ }^{\text {w }}$ Predominate race of P. parasitica var. nicotianae in each field was determined based on black shank incidence on cv. NC 1071 that has the Php gene and very low partial resistance from Florida 301.

x There were 25 cultivars: 8 with various levels of partial resistance inherited from Florida 301 (group I); 14 with the Php gene and various levels of partial resistance from Florida 301 (group II); 2 with resistance recently introduced to the United States from Zimbabwe and the Php gene (group III); and 1 with the same resistance as group III but without the Php gene (group IV).

${ }^{y}$ Logarithmic transformation of black shank disease index. Mean square (MS) derived from the type III sum of squares.

${ }^{\mathrm{z}}$ Asterisks indicate level of significance; $*$ and ** indicate $P<0.0001$ and $P \leq 0.05$, respectively. 
originated from Zimbabwe, appears more effective than the resistance from Florida

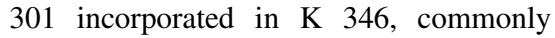
deployed in the United States, against race 0 of $P$. parasitica var. nicotianae (Table 4). That is, a low percentage of plants of RJR 15 had black shank symptoms and it was not statistically different than the percentage of NC 71 and RJR 75 that possess the Php gene (Table 4). RJR 15 was also the cultivar with the largest difference in symptomatic plants inoculated with race 0 versus race 3 (Table 4).

Effect of chemical controls on black shank incidence in on-farm studies. For the Bladen and Hoke County studies, where race 0 was the predominate race, field environment, cultivar, mefenoxam, and the cultivar-environment interaction were significant on black shank index (Table 5). NC 71 (group II) had a low black shank index with or without the application of mefenoxam (Fig. 1). With K 346 (group I), a cultivar with a high level of partial resistance to $P$. parasitica var. nicotianae races, three applications of mefenoxam provided the best control (Fig. 1). A single application of mefenoxam at a very early stage of tobacco growth (such as before planting tobacco or at first cultivation) significantly reduced the DI compared with the nontreated control (Fig. 1).

For the Forsyth-Surry field studies, where race 1 was predominant, only me- fenoxam application had a significant effect on black shank index (Table 6). Application of mefenoxam was very efficacious in controlling incidence of black shank, race 1 (Table 6; Fig. 2). Regardless of the cultivar planted, an early application of mefenoxam (i.e., applied before transplanting or at first cultivation) significantly reduced the incidence of black shank compared with the

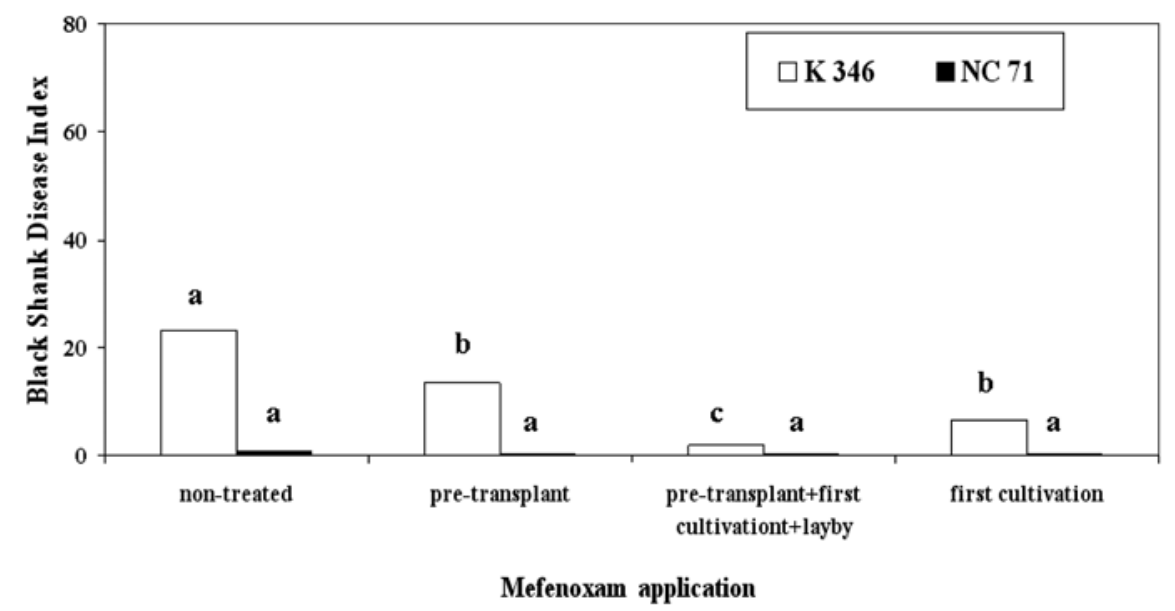

Fig. 1. Effect of mefenoxam application on black shank disease index in Bladen County in 2001 and in Hoke County in 2002. Race 0 was the predominate race of Phytophthora parasitica var. nicotianae in both studies. Mefenoxam was applied (i) before tobacco was transplanted in the field (pre-transplant); (ii) pre-transplant, at first cultivation, and at last cultivation (layby); and (iii) at first cultivation. Values are the means of the two studies. Bars with the same letters are not significantly different according to Fisher's least significant difference test $(P \leq 0.05)$.

Table 4. Black shank incidence 7, 14, and 21 days post inoculation (dpi) with race 0,1 , and 3 of Phytophthora parasistica var. nicotianae and black shank disease index (DI)

\begin{tabular}{|c|c|c|c|c|c|c|c|c|c|c|c|c|}
\hline \multirow[b]{3}{*}{ Cultivar $^{\mathrm{z}}$} & \multicolumn{12}{|c|}{ Plants infected by $P$. parasitica var. nicotianae $(\%)^{x}$} \\
\hline & \multicolumn{3}{|c|}{7 dpi } & \multicolumn{3}{|c|}{14 dpi } & \multicolumn{3}{|c|}{21 dpi } & \multicolumn{3}{|c|}{ DIy } \\
\hline & Race 0 & Race 1 & Race 3 & Race 0 & Race 1 & Race 3 & Race 0 & Race 1 & Race 3 & Race 0 & Race 1 & Race 3 \\
\hline K 346 & $13.00 \mathrm{a}$ & $5.00 \mathrm{~b}$ & $23.75 \mathrm{a}$ & $55.75 \mathrm{a}$ & $50.00 \mathrm{bc}$ & $31.25 \mathrm{a}$ & $80.00 \mathrm{a}$ & $57.50 \mathrm{bc}$ & $55.38 \mathrm{a}$ & $23.1 \mathrm{a}$ & $17.3 \mathrm{~b}$ & $18.9 \mathrm{a}$ \\
\hline RJR 15 & $0.00 \mathrm{~b}$ & $2.50 \mathrm{~b}$ & $21.25 \mathrm{a}$ & $8.25 \mathrm{~b}$ & $29.75 \mathrm{c}$ & $52.00 \mathrm{a}$ & $16.63 \mathrm{~b}$ & $48.63 \mathrm{c}$ & $65.13 \mathrm{a}$ & $3.0 \mathrm{~b}$ & $11.6 \mathrm{c}$ & $23.3 \mathrm{a}$ \\
\hline L8 & $0.00 \mathrm{~b}$ & $36.75 \mathrm{a}$ & $0.00 \mathrm{~b}$ & $0.00 \mathrm{~b}$ & $81.25 \mathrm{ab}$ & $0.00 \mathrm{~b}$ & $0.00 \mathrm{~b}$ & $83.38 \mathrm{ab}$ & $11.00 \mathrm{~b}$ & $0.0 \mathrm{~b}$ & $36.6 \mathrm{a}$ & $1.1 \mathrm{~b}$ \\
\hline NC 71 & $0.00 \mathrm{~b}$ & $40.38 \mathrm{a}$ & $0.00 \mathrm{~b}$ & $0.00 \mathrm{~b}$ & $90.00 \mathrm{a}$ & $0.00 \mathrm{~b}$ & $0.00 \mathrm{~b}$ & $100.00 \mathrm{a}$ & $0.00 \mathrm{~b}$ & $0.0 \mathrm{~b}$ & $40.1 \mathrm{a}$ & $0.0 \mathrm{~b}$ \\
\hline RJR 75 & $0.00 \mathrm{~b}$ & $4.13 b$ & $0.00 \mathrm{~b}$ & $0.00 \mathrm{~b}$ & $51.50 \mathrm{bc}$ & $0.00 \mathrm{~b}$ & $0.00 \mathrm{~b}$ & $78.38 \mathrm{ab}$ & $0.00 \mathrm{~b}$ & $0.0 \mathrm{~b}$ & $19.4 \mathrm{~b}$ & $0.0 \mathrm{~b}$ \\
\hline
\end{tabular}

${ }^{\mathrm{x}}$ Inoculum consisted of vinca (Catharanthus roseus L. Apocynaceae) leaf discs fully colonized by mycelium of each $P$. parasitica var. nicotianae race. Numbers are means of two experiments. Means within a column followed by the same letter are not significantly different according to Fisher's least significant difference test $(P \leq 0.05)$.

${ }^{y}$ DI was calculated from the three evaluations at 7, 14, and $21 \mathrm{dpi}$, with earlier evaluations more heavily weighted than the later ones. A disease index of 0 indicates no detectable levels of disease while that of 100 indicates that all plants had died within the period of evaluations.

${ }^{\mathrm{z}} \mathrm{K}$ 346: cultivar with high level of partial resistance from Florida 301 (group I), L8: burley tobacco breeding line that has the Phl gene for race 3 identification; NC 71: cultivar with the Php gene and some unknown level of partial resistance from Florida 301 (group II); RJR 75: cultivar with resistance recently introduced to the United States from Zimbabwe and the Php gene (group III); RJR 15: has the same resistance as group III but not the Php gene (group IV).

Table 5. Effect of flue-cured tobacco cultivar, mefenoxam application, and field environment on black shank disease index in two on-farm studies in Bladen and Hoke counties in North Carolina where race 0 was the predominate Phytophthora parasitica var. nicotianae race during the 2001 and 2002 growing seasons

\begin{tabular}{|c|c|c|c|c|}
\hline Source of variation ${ }^{y}$ & df & $\mathbf{M S}^{\mathbf{z}}$ & $F$ value & $P>F$ \\
\hline Cultivar & 1 & 8.51 & 238.7 & $<0.0001$ \\
\hline Mefenoxam application & 3 & 0.56 & 40.6 & $<0.0001$ \\
\hline Field environment & 1 & 1.44 & 15.8 & $<0.0001$ \\
\hline Cultivar $\times$ mefenoxam & 3 & 0.30 & 8.46 & 0.0001 \\
\hline Cultivar $\times$ field environment & 1 & 1.13 & 31.6 & $<0.0001$ \\
\hline Mefenoxam $\times$ field environment & 3 & 0.07 & 1.19 & 0.14 \\
\hline Cultivar $\times$ mefenoxam $\times$ field environment & 3 & 0.03 & 0.03 & 0.48 \\
\hline
\end{tabular}

y Cultivars used in the studies were K346: high partial resistance from Florida 301 (group I), and NC 71: Php gene and unknown level of partial resistance from Florida 301(group II). Field applications of mefenoxam were at the following tobacco growth stages: (i) before transplanting tobacco; (ii) before transplanting tobacco, at first cultivation, and at last cultivation; and (iii) at first cultivation.

${ }^{\mathrm{z}}$ Logarithmic transformation of black shank disease index. Mean square (MS) derived from the type III sum of squares. 
types of resistance to $P$. parasitica var. nicotianae. Bartlett's test indicated that each trial should be analyzed separately. The number of emerged roots from the buried stalk portion of the flue-cured cvs. K 326 and K 346 (group I) was significantly greater than the respective root numbers for cvs. NC 196 and SP 227 (group II) in all trials (Table 7). Although not always statistically significant, most roots were on K 326 (group I, low partial resistance), followed by K 346 (group I, high partial resistant), NC 196 (group II, moderate partial resistance and $P h p$ gene), and, finally, SP 227 (group II, high partial resistance and $P h p$ gene). The length of adventitious roots of NC 196 and SP 227 were always numerically less than for $\mathrm{K}$ 326 and K 346, although differences were not always statistically significant (Table 7). Overall, the cultivars of group I that do not possess the Php gene had more and longer adventitious roots than the cultivars of group II that possess the Php gene. In addition, K 346 and SPP 227, with high partial resistance, had fewer and shorter adventitious roots than K 326 and NC 196, with low to moderate levels of partial resistance.

\section{DISCUSSION}

Over the past 4 to 5 years, black shank incidence and severity has increased simultaneously with the increase in race 1 of $P$. parasitica var. nicotianae incidence $(32,33)$. The present study summarizes studies on cultivar performance and timing of mefenoxam application under the increased incidence of race 1 of $P$. parasitica var. nicotianae in the diverse environment of the coastal plain and piedmont of North Carolina. When race 1 prevails, partial resistance derived from Florida 301 incorporated in cultivars possessing the $P h p$ gene is necessary to effectively control black shank. Some newly introduced resistance from Zimbabwe is as effective in controlling race 1 of $P$. parasitica var. nicotianae as the Florida 301 type of resistance and looks promising to manage all races of black shank, based on laboratory experiments. Most of the modern cultivars possessing the $P h p$ gene that confirms complete resistance to race 0 of $P$. para- sitica var. nicotianae have moderate levels of partial resistance against all races of $P$. parasitica var. nicotianae and, therefore, are an effective tool to manage black shank only if they are coupled with chemical controls. In our studies, when race 1 was prevalent, mefenoxam was very effective to control black shank. An initial application of mefenoxam at an early stage of tobacco growth was very efficacious and appeared essential to successfully control the disease. This high efficacy may be related to the fact that adventitious roots, responsible for the majority of water and nutrient uptake in actively growing plants (13), are emerging at the same stage of tobacco growth.

Growers of flue-cured tobacco cultivate to build soil around the base of the plant and this practice may contribute to an increased black shank incidence, especially under wet conditions (35). When this practice was simulated in greenhouse experiments, fewer and shorter adventitious roots emerged from cvs. NC 196 and SP 227 than K 326 and K 346, an indication that the presence of the $P h p$ gene has a significant effect on the root development of tobacco cultivars. The number of adventitious roots was higher in $\mathrm{K} 326$ (with low partial resistance) than $\mathrm{K} 346$ (with high partial resistance). Although, in the present study, only the early root development was investigated, it has been previously reported that K 326 has a significantly larger root system than moderately resistant or highly resistant cultivars (25). Jones and Shew (26) observed that K 326 and Hicks (low level of resistance to $P$. parasitica var. nicotianae) produced more individual roots than G 28 (moderately resistant to $P$. parasitica var. nicotianae) or NC 82 (highly resistant to $P$. parasitica var. nicotianae).

Plants that produce fewer roots may be less likely to come in contact and become infected with pathogen propagules than those that have a greater rooting intensity, as a possible avoidance mechanism $(25,36)$. Cultivars with small root systems would require higher initial inoculum densities to contact similar numbers of propagules as cultivars with large root systems $(14,16)$. One way to reduce inoculum densities is by rotating tobacco with no host crops (33). In our field studies where race 1 of $P$. parasitica var. nicotianae was the predominate race, cultivars with the Php gene had a lower DI than cultivars with partial resistance in Yadkin County in 2007 and 2008, where tobacco was planted after no host crops. That was

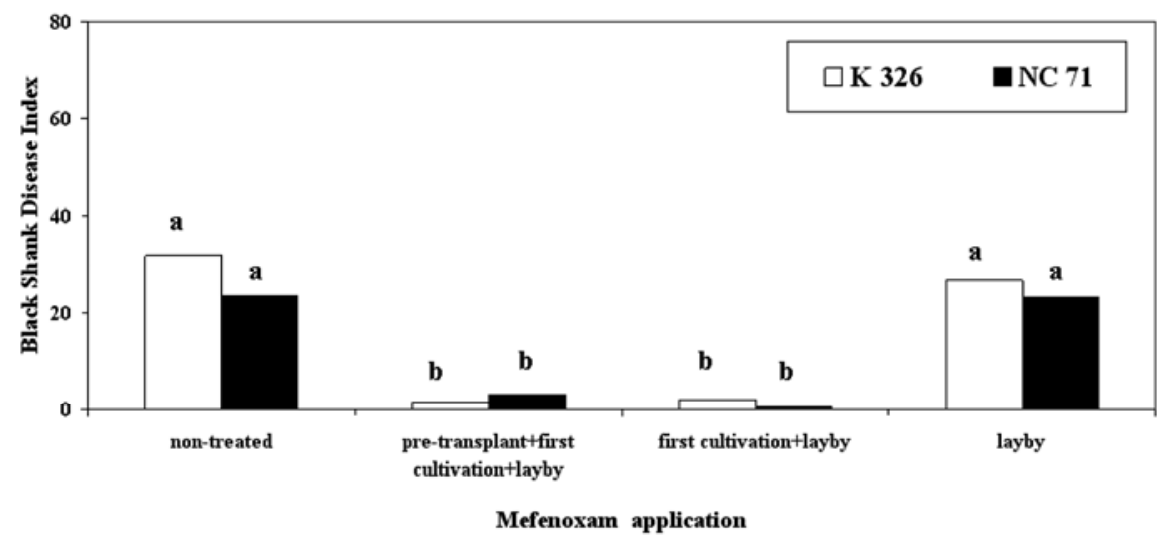

Fig. 2. Effect of mefenoxam application on black shank disease index in Forsyth and Surry Counties in 2007. Race 1 was the predominate race of Phytophthora parasitica var. nicotianae in both studies. Mefenoxam was applied (i) before tobacco was transplanted in the field (pre-transplant), at first cultivation, and at last cultivation (layby); (ii) at first cultivation and at layby; and (iii) at layby. Values are the means of the two studies. Bars with the same letters are not significantly different according to Fisher's least significant difference test $(P \leq 0.05)$.

Table 6. Effect of flue-cured tobacco cultivar, mefenoxam application, and field environment on black shank disease index in two on-farm studies in Forsyth and Surry Counties in North Carolina where race 1 was the predominate Phytophthora parasitica var. nicotianae race in 2007

\begin{tabular}{lllcc}
\hline Source of variation & df & MS $^{\mathbf{z}}$ & $\boldsymbol{F}$ value & \multicolumn{1}{c}{$\boldsymbol{P}>\boldsymbol{F}$} \\
\hline Cultivar & 1 & 0.11 & 0.58 & 0.45 \\
Mefenoxam application & 3 & 6.1 & 33.1 & 0.0001 \\
Field environment & 1 & 0.06 & 0.34 & 0.57 \\
Cultivar $\times$ mefenoxam & 3 & 0.01 & 0.10 & 0.96 \\
Cultivar $\times$ field environment & 1 & 0.05 & 0.31 & 0.58 \\
Mefenoxam $\times$ field environment & 3 & 0.02 & 0.74 & 0.53 \\
Cultivar $\times$ mefenoxam $\times$ field environment & 3 & 0.10 & 0.53 & 0.66 \\
\hline
\end{tabular}

${ }^{y}$ Cultivars used in the studies were K326: partial resistance from Florida 301 (group I), and NC 71: Php gene and unknown level of partial resistance from Florida 301 (group II). Field applications of mefenoxam were at the following tobacco growth stages: (i) before transplanting tobacco, at first cultivation, and at last cultivation; (ii) before transplanting tobacco and at first cultivation; and (iii) at first cultivation.

${ }^{\mathrm{z}}$ Logarithmic transformation of black shank disease index. Mean square (MS) derived from the type III sum of squares. 
not the case in Iredell (2007), Iredell (2008), and Surry (2007) Counties, where tobacco was planted right after tobacco. Initially, it was speculated that there was a difference among these fields in the proportion of race 1 versus 0 of $P$. parasitica var. nicotianae; however, the findings of the current study may suggest that, if density of inoculum is low, the cultivars possessing the $P h p$ gene that have a small root system may have fewer chances to be infected by $P$. parasitica var. nicotianae.

Continuous cropping of resistant tobacco cultivars in a field infested with a single race of $P$. parasitica var. nicotianae increases the selection of new virulent races $(2,10,39)$. In Georgia, race 1 has a wide range of virulence and many isolates are more aggressive than race 0 isolates (9). In North Carolina, race 1 of $P$. paraless aggressive than race 0 (3). Our field studies do not provide a clear conclusion; most cultivars of group I that have various levels of partial resistance had similar DIs when planted in fields where race 0 or race 1 were predominate. On the contrary, field environment, which may be associated with $P$. parasitica var. nicotianae available inoculum, soil characteristics, and other management practices, had a significant effect.

After the increase of race 1 of $P$. parasitica var. nicotianae, concerns about control of black shank with mefenoxam and choice of cultivars planted were raised. Cultivars such as NC 71 have been popular (33); however, they have low to moderate partial resistance to race 1 of $P$. parasitica var. nicotianae, some of them as low as $\mathrm{K}$ 326. In our studies, mefenoxam was very efficacious against race 1 of $P$. parasitica var. nicotianae, regardless of whether a cultivar of group I or group II was planted. Furthermore, mefenoxam application at an early stage of tobacco growth, such as at first cultivation that usually occurs 10 to 20 days after transplanting, appeared to be very critical. Progress in the development of adventitious root may provide an explasitica var. nicotianae has been reported as since their introduction in the mid-1990s

nation for mefenoxam effectiveness against black shank when it is initially applied at early stages of tobacco growth. Root system has important effects in water use efficiency, responses to fertilizers, and effectiveness of pesticides. Therefore, mefenoxam is absorbed by these additional, long, first-order roots, consequently not allowing $P$. parasitica var. nicotianae to colonize and infect the susceptible tobacco plants $(14,25)$. The combination of fewer infection sites (first-order roots) and inoculum inhibition by mefenoxam presence may effectively reduce epidemic development of black shank in the field.

Although management programs utilizing cultural practices, host resistance, and chemical treatments are used, losses in some years can be severe $(10,33)$. Cultivars with complete resistance to race 1 are not commercially available. In fields with both races present, the most effective approach to black shank management is the use of cultivars with high levels of partial resistance to all $P$. parasitica var. nicotianae races (40). The number of these cultivars is rather limited (24). Results of our study indicate that the resistance from Zimbabwe recently introduced to the United States may provide another source of resistance against all races of $P$. parasitica var. nicotianae beyond Florida 301 that has been extensively implemented in the United States. Very little is known about the origin of this resistance. Cvs. RJR 15 and RJR 75 are very vigorous (17) and, based on our field observations, have a large root system, equivalent to K 326 , which has low partial resistance from Florida 301 and very low resistance to black shank. We can only speculate that this resistance is very different than the one derived from Florida 301, and its exact mechanism remains to be investigated.

Many metalaxyl-resistant Phytophthora isolates are inherently fit and virulent and can compete with sensitive isolates $(15,41)$. When race 1 is predominant, mefenoxam application at first cultivation followed by a second one at layby should significantly reduce black shank incidence.

Table 7. Number and length of adventitious roots of four flue-cured cultivars, 18 days after transplanting 60 day-old tobacco seedlings in pots under greenhouse conditions ${ }^{y}$

\begin{tabular}{|c|c|c|c|c|c|c|}
\hline \multirow[b]{2}{*}{ Cultivar $^{\mathrm{z}}$} & \multicolumn{3}{|c|}{ No. of adventitious roots } & \multicolumn{3}{|c|}{ Adventitious root length $(\mathrm{mm})$} \\
\hline & Trial 1 & Trial 2 & Trial 3 & Trial 1 & Trial 2 & Trial 3 \\
\hline K 326 & $30.56 \mathrm{a}$ & $21.22 \mathrm{a}$ & $15.11 \mathrm{a}$ & $65.16 \mathrm{a}$ & 99.74 a & $71.85 \mathrm{a}$ \\
\hline K 346 & $15.33 \mathrm{~b}$ & $17.89 \mathrm{a}$ & $16.44 \mathrm{a}$ & $73.43 \mathrm{a}$ & $93.44 \mathrm{a}$ & $72.91 \mathrm{a}$ \\
\hline NC 196 & $9.00 \mathrm{c}$ & $9.89 \mathrm{~b}$ & $6.44 \mathrm{~b}$ & $38.04 \mathrm{~b}$ & $66.35 \mathrm{ab}$ & $48.07 \mathrm{a}$ \\
\hline SP 227 & $8.78 \mathrm{c}$ & $3.67 \mathrm{c}$ & $5.00 \mathrm{~b}$ & $32.97 \mathrm{~b}$ & $49.62 \mathrm{~b}$ & $46.70 \mathrm{a}$ \\
\hline
\end{tabular}

y Tobacco seedlings were planted so that $5 \mathrm{~cm}$ of the stalk base would be covered with the soil mixture, simulating the depth of tobacco field-grown transplants. Mean number and length of adventitious roots are average of three replications. Means within a column followed by the same letter are not significantly different according to Fisher's least significant difference test $(P \leq 0.05)$.

${ }^{\mathrm{z}}$ Cultivars used in the studies represented the two major groups of tobacco cultivars currently used in the United States: K346: high partial resistance from Florida 301 (group I), K326: low partial resistance from Florida 301 (group I), NC 196: Php gene and unknown level of partial resistance from Florida 301 (group II); and SP 227: Php gene and unknown level of partial resistance from Florida 301 (group II).
Under severe black shank incidence, mefenoxam applications starting at an early tobacco growth stage are recommended, with at least a 2-year rotation and the use of a resistant cultivars (40).

\section{ACKNOWLEDGMENTS}

We thank the North Carolina Tobacco Research Commission and Tobacco Foundation for financial support; and T. Sutton, R. Lewis, and C. S. Johnson for critical review of the manuscript before submission.

\section{LITERATURE CITED}

1. Apple, J. L. 1962. Physiological specialization within Phytophthora parasitica var. nicotianae. Phytopathology 52:351-354.

2. Apple, J. L. 1967. Occurrence of race 1 of Phytophthora parasitica var. nicotianae in North Carolina and its implications in breeding for disease resistance. Tob. Sci. 11:79-83.

3. Carlson, R. R., Wolff, M. F., Shew, H. D., and Wernsman, E. A. 1997. Inheritance of resistance to race 0 of Phytophthora parasitica var. nicotianae from the flue-cured tobacco cultivar Coker 371 Gold. Plant Dis. 81:1269-1274.

4. Chaplin, J. F. 1962. Transfer of black shank resistance from Nicotiana plumbaginifolia to flue-cured N. tabacum. Tob. Sci. 6:184-189.

5. Chaplin, J. F. 1966. Comparison of tobacco black shank resistance from four sources. Tob. Sci. 10:55-58.

6. Cohen, Y., and Coffey, M. D. 1986. Systemic fungicides and the control of oomycetes. Annu. Rev. Phytopathol. 24:311-339.

7. Collins, G. B., Legg, P. D., Litton, C. C., and Stokes, G. W. 1971. Locus homology in two species of Nicotiana. J. Hered. 62:288-290.

8. Csinos, A. S. 1999. Stem and root resistance to tobacco black shank. Plant Dis. 83:777-780.

9. Csinos, A. S. 2005. Relationship of isolate origin to pathogenicity of race 0 and 1 of Phytophthora parasitica var. nicotianae on tobacco cultivars. Plant Dis. 89:332-337.

10. Csinos, A. S., and Bertrand, P. F. 1994. Distribution of Phytophthora parasitica var. nicotianae races and their sensitivity to metalaxyl in Georgia. Plant Dis. 78:471-474.

11. Csinos, A. S., Fortnum, B. A., Gayed, S. K., Reilly, J. J., and Shew, H. D. 1986. Evaluating chemicals for control of soilborne pathogens on tobacco. Pages 231-236. in: Methods for Evaluating Pesticides for Control of Plant Pathogens. K. D. Hickey, ed. American Phytopathological Society Press, St. Paul, MN.

12. Csinos, A. S., Fortnum, B. A., Powell, N. T., Reilly, J. J., and Shew, H. D. 1984. Resistance of tobacco cultivars and candidate cultivars to Phytophthora parasitica var. nicotianae. Tob. Sci. 28:153-155.

13. DeRoo, H. C. 1961. Deep tillage and root growth. A study of tobacco growing in sandy loam soil. Bull. Conn. Agric. Exp. Stn. 644.

14. English, J. T., and Mitchell, D. J. 1989. Use of morphometric analysis for characterization of tobacco root growth in relation to infection by Phytophthora parasitica var. nicotianae. Plant Soil 113:243-249.

15. Ferrin, D. M., and Kabashima, J. N. 1991. In vitro intensitivity to metalaxyl of isolates of Phytophthora citricola and P. parasitica from ornamental hosts in Southern California. Plant Dis. 75:1041-1044.

16. Ferrin, D. M., and Mitchell, D. J. 1986. Influence of initial density and distribution of inoculum on the epidemiology of tobacco black shank. Phytopathology 76:1153-1158.

17. Fisher, L. R., Smith, W. D., and Barnes K. 2010. Selecting a variety. Pages $19-43$ in: FlueCured Tobacco Guide. N. C. Coop. Ext. Serv. Bull., North Carolina State University, Raleigh.

18. Gallup, C. A., and Shew, H. D., 2006. Race 
stability in Phytophthora nicotianae, the causal agent of black shank of tobacco. (Abstr.) Phytopathology 96:S37.

19. Goins, R. B., and Apple, J. L. 1970. Inheritance and phenotypic expression of a dominant factor for black shank resistance from Nicotiana plumbaginifolia in a Nicotiana tabacum milieu. Tob. Sci. 14:7-11.

20. Guttiérez, W. A., and Mila A. L. 2007. A rapid technique for determination of races of Phytophthora nicotianae on tobacco. Plant Dis. 91:985-989.

21. Guttiérez, W. A., and Shew, H. D. 2000. Factors that affect development of collar rot on tobacco seedlings grown in greenhouses. Plant Dis. 84:1076-1080.

22. Hendrix, J. W., and Apple, J. L. 1967. Stem resistance to Phytophthora parasitica var. nicotianae in tobacco derived from Nicotiana longiflora and N. plumbaginifolia. Tob. Sci. 11:148-150.

23. Huisman, O. C. 1982. Interrelations of root growth dynamics to epidemiology of rootinvading fungi. Annu. Rev. Phytopathol. 20:303-327.

24. Johnson, C. S., Pattison, J. A., Clevinger, E. M., Melton, T. A., Fortnum, B. A., and Mila, A. 2008. Clarifying the source of black shank resistance in flue-cured tobacco. Plant Management Network. Online: Plant Health Progress doi: 1094/PHP-2008-0618-02-RS

25. Jones, K. J. 1990. Components of resistance in Nicotiana tabacum to Phytophthora parasistica var. nicotianae. Ph.D. thesis, Department of Plant Pathology, North Carolina State University, Raleigh.

26. Jones, K. J., and Shew, H. D. 1995. Early season root production and zoospore infection of cultivars of flue-cured tobacco that differ in level of partial resistance to Phytophthora parasitica var. nicotianae. Plant Soil 172:55-61.
27. Kannwischer, M. E., and Mitchell, D. J. 1978 The influence of a fungicide on the epidemiology of black shank on tobacco. Phytopathology 68:1760-1765.

28. Lamprecht, M. P. 1973. Breeding flue-cured tobacco resistant to South African black shank (Phytophthora nicotianae (B. de Haan) var. nicotianae). Agroplantae 5:67-72.

29. Lamprecht M. P., Prislloo, G. C., and van Wyk, R. J. 1974. Inheritance of resistance to race 2 of the black shank fungus Phytophthora nicotianae var. nicotianae. Agroplantae 6:73-76.

30. Litton, C. C., Collins, G. B., and Legg, P. D. 1970. Reaction of Nicotiana tabacum and other $N$. species to race 0 and 1 of Phytophthora parasitica var. nicotianae. Tob. Sci. 14:128-130.

31. McIntyre, J. L., and Taylor, G. S. 1978. Race 3 of Phytophthora parasitica var. nicotianae. Phytopathology 68:756-760.

32. Mila, A. L., and Guttierez, W. 2007. Prevalence of races of Phytophthora nicotianae in North Carolina. (Abstr.) Phytopathology 97:S76.

33. Mila, A. L., and Radcliff, J. 2009. Managing Diseases. Pages 140-174 in: Flue-Cured Tobacco Guide. N. C. Coop. Ext. Serv. Bull., North Carolina State University, Raleigh.

34. Shew, H. D. 1984. In vitro response of Phytophthora parasitica var. nicotianae isolates to metalaxyl. Plant Dis. 68:764-766.

35. Shew, H. D. 1991. Black shank. Pages 17-21 in: Compendium of Tobacco Diseases. H. D. Shew and G. B. Lucas, eds. American Phytopathological Society Press, St. Paul, MN.

36. Shew, H. D., and Shew, B. B. 1984. Host resistance. Pages 244-275 in: Epidemiology and Management of Root Diseases. C. L. Campbell and D. M. Benson, eds. SpringlerVerlag, Heidelberg, Germany.
37. Silber, G., and Heggestad, H. E. 1963. Com parative black shank resistance of Beinhart 1000 (Quindiaz), N.C. 5346, and Rg in F1 generation involving various tobacco types. Tob. Sci. 7:144-147.

38. Staub, T. H., and Young, T. R. 1980. Fungitoxicity of metalaxyl against Phytophthora parasitica var. nicotianae. Phytopathology 70:797801.

39. Sullivan, J. M., Melton, T. A., and Shew, H. D. 2005. Fitness of races 0 and 1 of Phytophthora parasitica var. nicotianae. Plant Dis. 89:12201228.

40. Sullivan, J. M., Melton, T. A., and Shew, H. D. 2005. Managing the race structure of Phy tophthora parasitica var. nicotianae with cultivar rotation. Plant Dis. 89:1285-1294.

41. Timmer, L. W., Graham, J. H., and Zitko, S. E. 1998. Metalaxyl-resistant isolates of Phy tophthora nicotianae: occurrence, sensitivity, and competitive parasitic ability on citrus. Plant Dis. 82:254-261

42. Tisdale, W. S. 1931. Development of strains of cigar wrapped tobacco resistant to black shank (Phytophthora parasitica Breda de Haan). Fla Agric. Exp. Stn. Bull. 226:1-45.

43. Valleau, W. D., Stokes, W., and Johnson, E. M. 1960. Nine years experience with the Nicotiana longiflora factor for resistance to Phytophthora parasitica var. nicotianae in the control of black shank. Tob. Sci. 4:92-94.

44. van Jaarsveld, E., Wingfield, M. J., and Drenth, A. 2002. Evaluation of tobacco cultivars for resistance to races of Phytophthora nicotianae in South Africa. J. Phytopathol. 150:456-462.

45. Wernsman, E. A., Matzinger, D. F., and Powell, N. T. 1974. Genetic investigations of intraspecific and interspecific sources of blank shank resistance in tobacco. Tob. Sci. 18:1518. 